\title{
Direction of Susceptance and Conductance Acoustic Reflexes at High Probe Frequencies
}

\author{
Louise Reynolds and Lucille P Morton
}

\author{
Department of Logopaedics \\ University of Cape Town
}

\begin{abstract}
Previous investigations have shown that for low probe frequencies $(220$ and $660 \mathrm{~Hz})$ the direction of susceptance and conductance reflexes is related to baseline transmission properties. Previously documented reflex patterns, caused by the stiffening of the ossicular chain, are characterised by decreases in both components at $220 \mathrm{~Hz}$ (-B-G) and increases in susceptance and decreases in conductance $(+B-G)$ at $660 \mathrm{~Hz}$. In the present study, the direction of susceptance and conductance acoustic reflexes was investigated at a probe frequency of $1000 \mathrm{~Hz}$, where ears are expected to be less stiffness dominated than at the low frequencies, and for which there is little description of reflex patterns in the published literature. The pattern of ipsilateral susceptance and conductance reflexes from 30 normal ears was recorded across a wide intensity range at this probe frequency for three stimulus frequencies $(0.5,1$ and $2 \mathrm{kHz})$.

Reflexes were classified as either increases ( + ) or decreases $(-)$ for each component, at threshold and at suprathreshold intensity levels. Ears were grouped according to transmission properties at $1000 \mathrm{~Hz}$, and reflex patterns observed within each group of subjects were examined. Patterns observed in these subjects at the $1000 \mathrm{~Hz}$ probe frequency included: $+B-G ;+B+G ;-B+G$ and $-B-G$. There appeared to be a relationship between baseline transmission and reflex patterns. Further, patterns appear to be consistent with theoretical models of the effect of the acoustic reflex, particularly for ears where stiffness is significant in the baseline condition. The effect of the reflex for mass dominated systems requires further investigation.
\end{abstract}

\section{OPSOMMING}

Vorige navorsing het bewys'dat vir laetoonfrekwensies (220 en $660 \mathrm{~Hz}$ ) die rigting van susseptansie- en konduktansiereflekspatrone aan basiese transmissie-eienskappe verwant is. Vorige gedokumenteerde reflekspatrone, veroorsaak deur die verstywing van die ossikulere ketting, word gekenmerk deur verlagings in albei komponente by $220 \mathrm{~Hz}$ (-B-G) en verhogings in susseptansie en verlagings in konduktansie (+B-G) by $660 \mathrm{~Hz}$. In die huidige studie, is die rigting van susseptansie-en konduktansie-akoestiese reflekse by toonfrekwensie van $1000 \mathrm{~Hz}$ ondersoek, waar dit verwag is dat die ore minder stramheidoorheers sal wees as by die lae frekwensies. Daar bestaan beperkte beskrywings in die gepubliseerde literatuur oor reflekspatrone. Die patroon vir ipsilaterale susseptansie en konduktansiereflekse met 30 normale ore is vir ' $n$ wye intensiteitsreeks aangeteken teen die toonfrekwensie vir drie stimulusfrekwensies $(0.5,1$ en 2 $k H z$ ).

Reflekse is geklassifiseer as verhogings (+) of verminderings (-) van elke komponent, op drempel-en bo-drempelintensiteitsulakke. Refleksie is gegroepeer volgens die transmissie-eienskappe by $1000 \mathrm{~Hz}$, en reflekspatrone waargeneem in elke groep is ondersoek. Patrone wargeneem in die ore by die $1000 \mathrm{~Hz}$ toonfrekwensie het die volgende ingesluit: $+B-G,+B+G,-B+G$ en $-B-G$. 'n Moontlike verwantskap is wargeneem tussen basislynkondisie-transmissie- en reflekspatrone. Verder, blyk die patrone verenigbaar te wees met teoretiese modelle van die effek van die akoestiese refleks, in die besonder vir ore waarin stramheid betekenisvol in die basislynkondisie is. Die effek van die refleks vir massa oorheersende stelsels vereis verdere navorsing.

The effect of the acoustic reflex on admittance components (susceptance and conductance) is dependent on the baseline transmission properties of the middle ear at the particular probe frequency used in the immitance recording (Feldman \& Williams, 1976). This has been clearly demonstrated for low probe frequencies by researchers such as Feldman \& Williams (1976); Lutman \& Martin (1979) and Lutman, McKenzie \& Swan (1984). However, the effect of the acoustic reflex on susceptance and conductance measures for higher probe frequencies, where baseline transmission is either close to the natural frequency of the middle ear, or mass dominated, has not been fully discussed in the published literature. With the current availability of measuring devices which allow for the investigation of middle ear function across a wide frequency range, the clinical audiologist is now able to conduct acoustic reflex measures at a range of probe frequencies, but may encounter difficulty in the interpretation, given the varying effects of the reflex as being either an increase or decrease in each of the admit- 
tance components. Having an expectation of the usual reflex pattern (increase of decrease in each of the components) in normal ears at higher probe frequencies, might assist the audiologist in reflex pattern interpretation.

During acoustic reflex measurements the value of admittance components (susceptance $(B)$ and conductance (G)) with the stapedius muscle at rest are compared to the values of these components with the acoustic reflex activated (Wiley \& Block, 1979). The equipment used in many clinical investigations of the acoustic reflex baselines the admittance value measured at the probe tip in the resting state to zero, and then represents the admittance change associated with the activation of the reflex as an increase (+) or decrease (-) relative to zero. Changes in middle ear admittance or impedance (or components thereof) caused by the reflex have the property of direction (+ or -) together with the properties of magnitude and shape. The direction of reflex patterns, at threshold and suprathreshold intensity levels of the reflex eliciting stimulus, for the components of admittance have been investigated extensively using probe frequencies of 220 and $660 \mathrm{~Hz}$ and in spite of different methodologies, similar findings are reported across studies. At a low probe frequency $(220 \mathrm{~Hz})$ the normal ear is stiffness dominated (Shanks, Lilly, Margolis, Wiley \& Wilson, 1988). Under these conditions, the reflex induced stiffness increase, is measured as decreases in both susceptance and conductance (-B-G), as shown by Feldman \& Williams (1976) and Lutman \& Martin (1977). Increases in susceptance and decreases in conductance (+B-G) have been observed at a slightly higher probe frequency $(660 \mathrm{~Hz})$ by the same researchers. At this probe frequency the middle ear system is still expected to be stiffness dominated, but with a significant contribution from the resistance component to overall impedance (Shanks et al., 1988). The decrease in susceptance at $220 \mathrm{~Hz}$ and the increase in susceptance at $660 \mathrm{~Hz}$ are, however, both representative of the same phenomenon of stiffening of the ossicular chain. It is well established that the effect of the reflex results in an increase in negative reactance (stiffness), at least for these low probe frequencies (Lutman \& Martin, 1979). The addition of negative reactance yields either increases or decreases in susceptance due to the complex relationship between the components of admittance and impedance, which rules that susceptance is not the direct reciprocal of reactance, and neither is conductance the direct reciprocal of resistance (Van Camp \& Creten, 1976). Rather, a complex relationship exists between these components (Berlin \& Cullen, 1980). In addition, when changes to reactance and/or resistance occur at the level of the tympanic membrane, these have a nonlinear relationship to impedance measurements made at the probe tip (Margolis, 1981). To avoid this complexity, Van Camp \& Creten (1976) explain that immittance measures made in the clinical setting are usually made in admittance (or components thereof). Thus, although the reflex may be considered to cause an increase in negative reactance, the resulting susceptance measurement is more complex and is dependent on the baseline relationship between reactance and resistance. Clinical measures in admittance quantities at the probe tip may therefore yield various patterns, depending on the baseline transmission proper- ties of the middle ear.

Little research has been reported on the effect of the reflex on admittance components, when recorded at probe frequencies above $660 \mathrm{~Hz}$. Bennett \& Weatherby (1979) have investigated the effect of the reflex at a fixed stimulus intensity for a wide range of probe frequencies. The measures were made in admittance, but results were reported in impedance components. Reynolds (1991), reporting on an exploratory investigation of the effect of the reflex using measures similar to those conventionally adopted in the clinical setting, found that for a higher probe frequency $(1000 \mathrm{~Hz})$ the effect of the reflex was to increase both the admittance components $(+\mathrm{B}+\mathrm{G})$ at threshold for ears where the probe frequency was close to the resonant frequency.

Suprathreshold investigations of the acoustic reflex have indicated that the direction of the reflex may change at suprathreshold intensity levels. Lutman \& Martin (1977); Wilson \& McBride (1978) and Lutman, McKenzie \& Swan (1984) have demonstrated the susceptance component when suprathreshold reflex patterns are compared to threshold reflex patterns for a $660 \mathrm{~Hz}$ probe frequency. In these investigations, the susceptance reflex patterns shifted from an increase $(+B)$ to a decrease (-B) with increases in reflex eliciting stimulus intensity. The phenomenon of direction change for the conductance component has not been reported in the published literature. However, Reynolds (1991) found that direction changes occurred for the conductance component ( $+G$ at threshold became $-G$ at suprathreshold levels) at a $1000 \mathrm{~Hz}$ probe frequency. This phenomenon suggests that the effect of the reflex at the higher probe frequency is to add negative reactance to the system, such that with stronger contractions of the acoustic reflex above threshold, reflex patterns resemble those seen at low intensities for stiffer systems (i.e., at lower probe frequencies). In order to provide an expectation for the clinical audiologist as to when to expect certain patterns of direction and direction change, an investigation of the relationship between baseline transmission properties and the direction of the reflex pattern at both threshold and suprathreshold levels was conducted in the present investigation. The aim of the present study was to relate baseline transmission properties to susceptance and conductance reflex patterns using a high probe frequency $(1000 \mathrm{~Hz})$, and measured at the probe tip as is conventional in clinical investigations.

\section{METHODOLOGY}

\section{SUBJECTS}

Thirty subjects were chosen to represent a sample of normal young ears. Subjects were required to be between the ages of 18 to 25 years; to have no known history of ear pathology; to have normal hearing thresholds (i.e. $<25 \mathrm{db} \mathrm{HL}$ ) at the octave frequencies 250 to $8000 \mathrm{~Hz}$; air bone gaps of less than $10 \mathrm{~dB}$; single peaked admittance tympanograms at a $226 \mathrm{~Hz}$ probe frequency and present ipsilateral acoustic reflexes at $0.5,1$ and $2 \mathrm{kHz}$ stimuli recorded at a probe frequency of $226 \mathrm{~Hz}$. One ear was used from each subject to allow for a wider spread of normal ears and prevent possible duplication of results, given the very'small interaural differences reported in subjects by Hall (1979) and Creten, Van de 
Heyning \& Van Camp (1985).

Subjects were divided into 5 groups according to their transmission properties at $1000 \mathrm{~Hz}$ determined by means of tympanometry at this probe frequency. The Vanhuyse, Creten \& Van Camp (1975) system of tympanogram classification was used. Subjects with similar transmission properties were grouped together. The division of subjects into groups is shown in Table 1. In addition, an estimation of resonance by means of identifying the natural frequency using multiple frequency tympanometry (see below) was made for each subject. Groups were also described in terms of the mean resonant frequency obtained.

\section{APPARATUS}

All audiometric evaluations were conducted using a GSI 16 Clinical Audiometer, with TDH-50P earphones and $B 71$ bone vibrator. This audiometer is calibrated in $\mathrm{dB}$ HL and meets the ANSI s.26-1981 standard for audiometers.

Immittance measures were made using the GSI 33 version 2 Middle Ear Analyser. This microprocessor based instrument meets the ANSI s3.39-1987 standard for acoustic- immittance instruments. The probe frequencies (including $1000 \mathrm{~Hz}$ ) are nominally set to 70 dB HL (Grason Stadler Instruction Manual, 1989). Ipsilateral reflex probe and stimulus tones are time multiplexed. For reflex measurements either susceptance or conductance changes can be displayed at one time. The instrument was calibrated for the specific altitude of the test environment ( 98 meters above sea level) as recommended by Lilly \& Shanks (1981). A calibration check following the manufacturer's instructions was carried out on each day of data collection.

All testing was completed in a sound treated environment.

\section{PROCEDURE}

Púre tone thresholds were determined according to stándard audiometric procedure (Yantis, 1985).

Baseline susceptance and conductance values in the uncontracted state were obtained from simultaneously recorded susceptance and conductance tympanograms obtained using a $1000 \mathrm{~Hz}$ probe frequency. The pressure sweep for the tympanograms was in a positive to negative direction, pressure was varied at a rate of 50 daPa per second, between +200 and $-300 \mathrm{daPa}$. The baseline susceptance and conductance values were recorded from the tympanometric peak pressures for each component. For notched tympanograms the central extremum was used for quantification. The recording of susceptance and conductance values at tympanometric peak was selected in preference to ambient pressure due to this being a more stable measure (Wilson, Shanks \& Kaplan, 1984) and because the reflex was automatically recorded at tympanometric peak pressure. A decrease in pressure (change in pressure from positive to negative) at a low rate was used as these conditions yield less complex tympanometric configurations (Margolis, Van Camp, Wilson \& Creton, 1985).

Multiple frequency tympanometry was conducted for all ears in order to approximate resonance. The multifrequency tympanometry programme on the GSI 33 was used for this purpose. This programme consists of frequency sweeps $(200$ to $2000 \mathrm{~Hz})$ at $+200 \mathrm{daPa}$ and tympanometric peak (determined from the $226 \mathrm{~Hz}$ admittance tympanogram). The frequency at which the difference between the susceptance value at $+200 \mathrm{daPa}$ and tympanometric peak is at a minimum is used as an approximation of middle ear resonance (Funasaka \& Kumakawa, 1988). In order to ensure that an adequate approximation of resonance was obtained, susceptance and conductance tympanograms were recorded at this frequency to check for the $3 \mathrm{~B} 1 \mathrm{G}$ configuration.

Reflex growth functions were obtained ipsilaterally at the $1000 \mathrm{~Hz}$ probe frequency using three stimulus frequencies $(0.5,1$ and $2 \mathrm{kHz})$. Stimulus intensity ranged from levels below expected reflex thresholds ( 66 $\mathrm{dB} \mathrm{HL}$ ) to the maximum output of the GSI 33 (110 dB $\mathrm{HL}$ for 0.5 and $1 \mathrm{kHz}$ and $104 \mathrm{~dB} \mathrm{HL}$ for $2 \mathrm{kHz}$ ). Although the intensity of the reflex eliciting stimulus reached high levels, such intensity levels have previously been incorporated into studies investigating the effect of the reflex, such as that by Lutman et al., (1984). A $4 \mathrm{~dB}$ increment size was used. Stimulus duration was kept constant at 1.5 seconds for each stimulus presentation (1.5 seconds being the default parameter for the GSI 33). For each of the stimulus frequencies susceptance recordings preceded conductance recordings and reflex eliciting stimuli were presented in an ascending manner.

The amount of mmho change at each intensity level was recorded. This was classified as either an increase (+) or decrease (-) in the value of the component. This classification was made for each stimulus intensity level.

\section{ANALYSIS OF THE DATA}

The results obtained for the $1000 \mathrm{~Hz}$ probe frequency were analysed within each of the subject groups shown in Table 1 as suggested by Sprague, Wiley \& Block (1981) and Greenfield, Wiley \& Block (1985) as wide variability across subjects is reported when similar patterns are not grouped together first. This was considered important as trends in the data may obscure individual findings (Block \& Wiley, 1986). The reflex patterns observed for each of the three stimulus frequencies were analysed together. This was in order to increase the pool of reflex patterns obtained from the subjects. Reynolds (1991) reported that there was no significant difference between these three frequencies in terms of the reflex patterns observed, and no further investigation of any frequency effect was made in the present study.

The distribution of reflex patterns at threshold and where direction changes at suprathreshold levels occurred, was recorded for each group of ears. Threshold was defined as the intensity level at which both of the components demonstrated reflexes which met the GSI criterion of $0.09 \mathrm{mmho}$ for the $1000 \mathrm{~Hz}$ probe frequency.

The range of reflex patterns was recorded and frequency counts made of the number of times subjects within each of the groups demonstrated the pattern. The results were presented in tabular form.

\section{RESULTS AND DISCUSSION}

As the three stimulus frequencies $(0.5,1$ and $2 \mathrm{kHz}$ ) were pooled for each of the subjects in the present study, the total number of observations of reflex patterns is 
90 , that is three times the number of ears investigated. The total number of observations ( $n$ ) in each group is also three times that of the number of ears allocated to the groups shown in Table 1.

The distribution of reflex patterns across the groups at threshold shown in Table 2 , indicates that a wider range of reflex patterns was seen at the $1000 \mathrm{~Hz}$ probe frequency than is reported in the published literature. The range of patterns recorded at the subjects' reflex thresholds included: $+B-G,+B+G,-B+G$ and $-B-G$. The threshold pattern can be seen to occur along a continuum, being determined by baseline characteristics and changing as the natural frequency of the system decreases. At suprathreshold intensity levels the direction of $+B+G$ threshold patterns changed to $+B-G$, and threshold patterns of $-B+G$ to those of $+B+G$ at suprathreshold intensity levels.

The theoretical continuum of results as a function of mass and stiffness characteristics and probe frequencies is illustrated in Table 3 . Although the number of

Table 1. Transmission propertie of ears at the $100 \mathrm{~Hz}$ probe signal which formed the basis for the division of ears into 5 groups

\begin{tabular}{|c|c|}
\hline GROUP 1: & $\begin{array}{l}\text { Type } 1 \text { tympanograms ( } 1 \mathrm{~B} 1 \mathrm{G}) \text {. All tympanometric peak } \mathrm{B} \text { values larger than tympanometric peak } \\
\text { G values and all } \mathrm{B} \text { values positive } \\
\mathrm{n}-9 \\
\text { Mean resonant frequency }=120 \mathrm{~Hz}\end{array}$ \\
\hline GROUP 2: & $\begin{array}{l}\text { Type } 2 \text { tympanograms }(3 B 1 G) \text {. All tympometric peak } B \text { values larger than } G \text { values and all } B \\
\text { values positive } \\
\mathrm{n}=4 \\
\text { Mean resonant frequency }=1062 \mathrm{~Hz}\end{array}$ \\
\hline GROUP 3: & $\begin{array}{l}\text { Type } 2 \text { tympanograms ( } 3 \mathrm{~B} 1 \mathrm{G}) \text {. All tympanometric peak } \mathrm{B} \text { values smaller than typanometric peak } \\
\mathrm{G} \text { values and all } \mathrm{B} \text { values positive } \\
\mathrm{n}=6 \\
\text { Mean resonant frequency }=950 \mathrm{~Hz}\end{array}$ \\
\hline GROUP 4: & $\begin{array}{l}\text { Type } 3 \text { tympanograms ( } 3 \mathrm{~B} 3 \mathrm{G}) \text {. All tympanometric peak } \mathrm{B} \text { values smaller than tympanometric peak } \\
\mathrm{G} \text { values and all } \mathrm{B} \text { values positive } \\
\mathrm{n}=7 \\
\text { Mean resonant frequency }=707 \mathrm{~Hz}\end{array}$ \\
\hline GROUP 5: & $\begin{array}{l}\text { Type } 3 \text { tympanograms ( } 3 \mathrm{~B} 3 \mathrm{G}) \text { all tympanometric peak } \mathrm{B} \text { values negative } \\
\mathbf{n}=4 \\
\text { Mean resonant frequency }=650 \mathrm{~Hz}\end{array}$ \\
\hline
\end{tabular}

Table 2. Susceptance and conductance reflex patterns at threshold and suprathreshold levels for each group, recorded for the three stimuli at the $1000 \mathrm{~Hz}$ probe frequency.

Where the direction of the reflex pattern ( $B$ or $G$ ) changed at suprathreshold intensity levels relative to threshold reflex patterns, the threshold and suprathreshold patterns are named and separated by a semicolon

\begin{tabular}{|c|c|c|c|c|c|}
\hline $\begin{array}{l}\text { Reflex patterns } \\
\text { for admittance } \\
\text { components }\end{array}$ & $\begin{array}{l}\text { Group } 1 \\
(\mathrm{n}=27)\end{array}$ & $\begin{array}{l}\text { Group } 2 \\
(\mathrm{n}=12)\end{array}$ & $\begin{array}{l}\text { Group } 3 \\
(\mathbf{n}=18)\end{array}$ & $\begin{array}{c}\text { Group } 4 \\
(\mathrm{n}=21)\end{array}$ & $\begin{array}{l}\text { Group } 5 \\
(\mathrm{n}=12)\end{array}$ \\
\hline$-B-G$ & & & & & 5 \\
\hline \multicolumn{6}{|l|}{$-B-G ;-B+G$} \\
\hline$-B+G$ & & & & 1 & 2 \\
\hline$-\mathrm{B}+\mathrm{G} ;+\mathrm{B}+\mathrm{G}$ & & & & 2 & 4 \\
\hline$+\mathrm{B}+\mathrm{G}$ & 1 & & 5 & 6 & 1 \\
\hline$+\mathrm{B}+\mathrm{G} ;+\mathrm{B}-\mathrm{G}$ & 8 & 2 & 11 & 7 & \\
\hline$+B-G$ & 18 & 10 & 2 & 5 & \\
\hline
\end{tabular}

Table 3. Continuum of results obtained in the present study indicating the relationship between reflex patterns at threshold and suprathreshold intensity levels and baseline transmission properties (máss dominance vs stifness dominance).

\begin{tabular}{|c|c|c|c|c|c|c|c|}
\hline \multirow[b]{2}{*}{ Threshold } & \multicolumn{3}{|c|}{ Stiffness dominated } & \multicolumn{2}{|c|}{$\langle<-\cdots+\cdots$} & \multicolumn{2}{|c|}{ Mass dominated } \\
\hline & $+B-G$ & $+B+G$ & $+B-G$ & $-B+G$ & $-B+G$ & $-B-G$ & $-B-G$ \\
\hline Suprathreshold & & $+B-G$ & & $+\mathrm{B}+\mathrm{G}$ & & $-B+G$ & \\
\hline
\end{tabular}


observations was too small to conduct any statistical analysis (Fitz-Gibbon \& Morris, 1987) it can be seen that the distribution of reflex patterns conforms to this continuum, with the majority of subjects in Group 1 (higher natural frequency, therefore more stiffness dominated) showing the $+B-G$ pattern, while the majority in Group 5 (lower natural frequency, therefore more mass dominated) showing the -B-G pattern at both levels. Thus as the natural frequency of the system moves from above the probe frequency to below it, one sees the progression of threshold reflex patterns from $+B-G$ to $-B-$ $G$. This suggests that the patterns may occur in each subject, were the probe frequency to be shifted to frequencies above and below the ear's natural frequency. Examples of each of the reflex patterns is shown in Figure 1 .

The +B-G pattern was seen most commonly for ears which were stiffness dominated (Groups 1 and 2). That is, the probe frequency was below the mean resonant frequency for both of these groups, which were $1200 \mathrm{~Hz}$ and $1062 \mathrm{~Hz}$ respectively. This pattern of $+B-G$ is consistent with the findings of Feldman \& Williams (1976) and Lutman et al., (1984) who used $660 \mathrm{~Hz}$ probe frequencies, at which many adult ears have similar transmission properties to those seen for these subjects in Groups 1 and 2. This pattern at $660 \mathrm{~Hz}$ has been related to an increase in stiffness when the reflex is activated (Feldman \& Williams, 1976). The transmission properties for most of the ears demonstrating the $+B-G$ pattern are possibly similar to the ears used in previous investigations at $660 \mathrm{~Hz}$, as they showed a fair contribution by negative reactance (stiffness) to overall impedance. This suggests that the effect of the reflex for the $+\mathrm{B}-\mathrm{G}$ pattern at the $1000 \mathrm{~Hz}$ probe frequency in the present study may also result from added stiffness when the reflex is activated. Although the effects on impedance components were not investigated in the present study, the results do appear to be consistent with theoretical models of the effect of the acoustic reflex presented by Lutman \& Martin (1979) and Lutman (1984).

The $+B+G$ pattern was clearly the most common pattern for ears in Group 3 where the mean resonant frequency $(950 \mathrm{~Hz}$ ) was just below the $1000 \mathrm{~Hz}$ probe frequency. The $+B+G$ pattern at threshold was also the most common pattern for ears in Group 4 in which the transmission properties were slightly above resonance, but not significantly mass dominated. This suggests that where ears demonstrate transmission properties close to resonance, the $+B+G$ pattern is expected. The $+B+G$ pattern shifted to $+B-G$ for several of the observations across groups 1 to 4 . A sketch of this phenomenon is shown in Figure 2. The direction change observed suggests that the effect of the reflex at suprathreshold intensity levels is to increase the amount of stiffness in the system. As the +B-G pattern at threshold in the present study is more commonly found for ears which are more stiff than those which show the $+B+G$ pattern at threshold, it appears that the direction change to the $+B-G$ pattern at suprathreshold levels is consistent with this addition of further stiffness at high intensities. These intensity related effects of the reflex are referred to in the theoretical models of the effect of the reflex (Lutman \& Martin, 1979).

The $-B+G$ pattern has not been reported previously.
This occurred only in ears which demonstrated transmission properties which were above resonance as shown by the tympanometric shape at $1000 \mathrm{~Hz}$ (Groups 4 and 5 ). The mean resonant frequencies of these two groups was $707 \mathrm{~Hz}$ and $650 \mathrm{~Hz}$ respectively, and this pattern suggests that for ears with low resonant frequencies, the expected reflex pattern for high probe frequencies could be $-B+G$ at threshold. The degree to which this pattern is expected appears to increase as the system becomes more mass dominated, as shown by this pattern being more common for Group 5 than for Group 4. The $-B+G$ pattern also showed a suprathreshold direction change (in some ears) to the $+B+G$ pattern. A sketch of this is shown in Figure 3. As with other direction changes discussed above, this direction change suggests that at higher intensities the effect of the reflex is to show added negative reactance, so that transmission approximates that usually seen for ears closer to resonance. Because the effect of: the reflex on reactance and resistance was not investigated directly, the patterns can only be simply related to patterns seen at lower probe frequencies. A more thorough investigation would be useful to relate measured admittance patterns to the effect on reactance and resistance. Such an investigation would need to correct probe tip measures to the level of the tympanic membrane as there is a nonlinear relationship between impedance measures made at the probe tip and those corrected to the lateral surface of the tympanic membrane (Margolis,

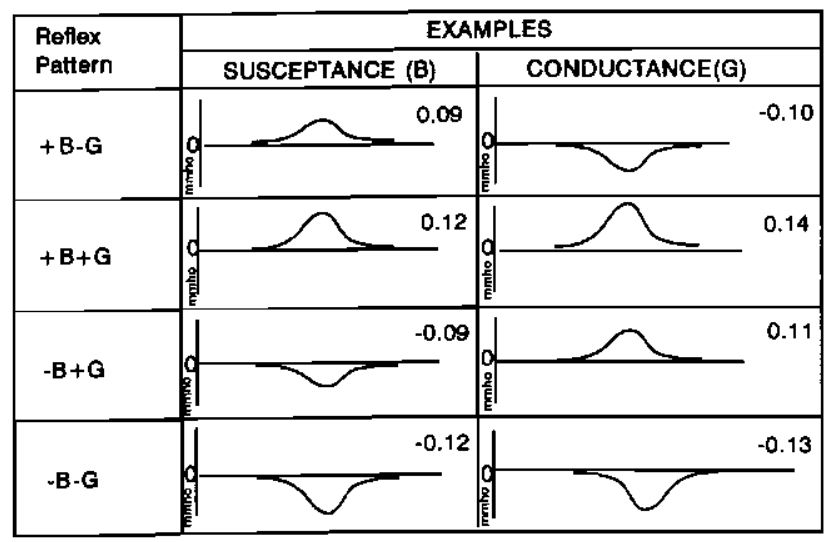

Figure 1. Sketch of the reflex patterns obtained at $1000 \mathrm{~Hz}$ probe frequency

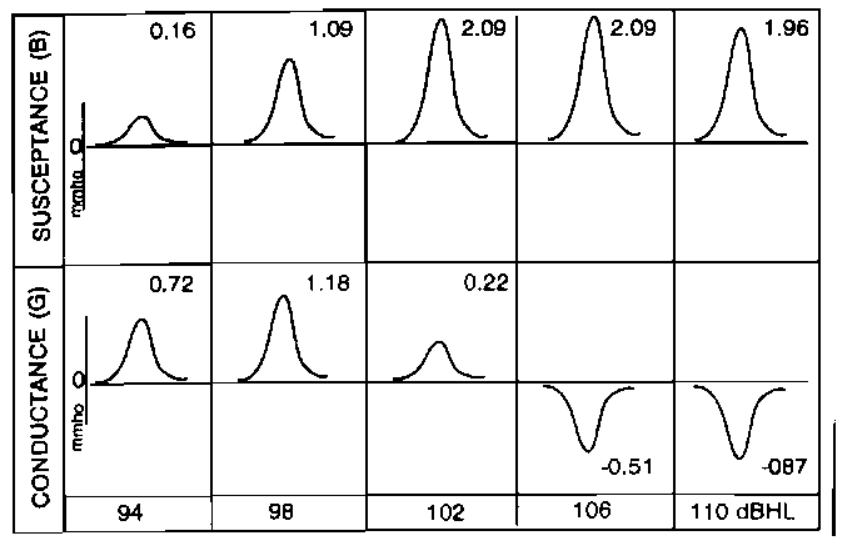

Figure 2. Sketch to show an example of the direction change in conductance $(+B+G ;+B-G)$ 
1981). Such an analysis was beyond the scope of the present investigation which was simply to document reflex patterns at higher probe frequencies, recorded in a similar fashion to conventional clinical measures.

The -B-G pattern was recorded only for ears which were clearly mass dominated at the $1000 \mathrm{~Hz}$ probe frequency (Group 5). This was interesting in that this pattern is the expected pattern also for ears which are clearly stiffness dominated, as shown by previous studies where the $220 \mathrm{~Hz}$ probe frequency was extensively investigated (for example, Feldman \& Williams, 1976; Lutman et al., 1984). None of these patterns demonstrated the direction change at suprathreshold intensity levels found with the other reflex patterns. This is interesting in that there is less documented evidence of the effect of the reflex for mass dominated systems (Lutman \& Martin, 1979) and it is possible that clearly mass dominated systems yield susceptance and conductance reflex patterns which do not reflect the added stiffness seen for ears with more stiffness in the baseline condition. As mentioned above, such conclusions cannot be drawn from the present investigation, but are discussed in more depth by Reynolds (1993). In addition, this aspect of the effect of the acoustic reflex requires further investigation.

\section{CONCLUSION}

Thus it appears from the results of this study that the direction of reflex patterns is determined by the natural frequency of the system in relation to the probe frequency. At suprathreshold levels the effect of the increase in intensity is to increase the stiffness, which for some ears results in a change in reflex pattern. The changed pattern is one which is characteristic of systems with a slightly higher natural frequency, i.e., at suprathreshold levels normal systems may behave like more stiffness dominated systems but not like more mass dominated systems. The results also suggest that the continuum of reflex patterns may be seen in all normal systems provided that one has a sufficient range of probe frequencies.

While further investigation of the effect of the reflex on underlying impedance components, particularly for mass dominated systems, is indicated these results do provide some guidelines to the clinical audiologist. Reflex patterns need to be interpreted in relation to the

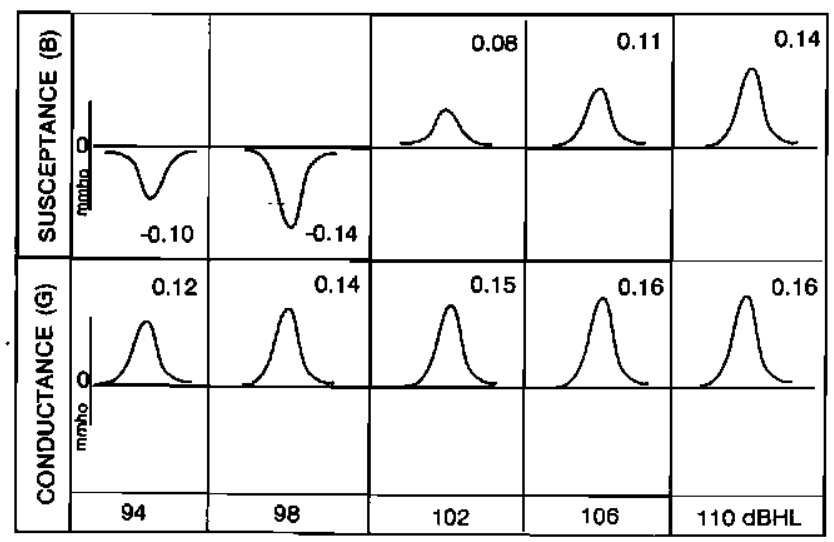

Figure 3. Sketch to show an example of the direction change in susceptance $(-B+G ;+B+G)$ natural frequency of the system and the probe frequency. Thus high probe frequency reflex patterns cannot be interpreted with confidence without and indication of the natural frequency of the system. Furthermore it would appear that the normal suprathreshold patterns can be explained by an increased stiffness occurring along a continuum, and that a departure from this may be abnormal. However, reflex patterns in abnormal systems need to be examined.

This study formed part of a masters dissertation $s u b$. mitted to the Faculty of Medicine, University of Cape Town.

\section{REFERENCES}

American National Standards Institute. (1981). Specifications for audiometers (ANSI s.26). New York, ANSI.

American National Standards Institute. (1987). Specifications for instruments to measure aural acoustic impedance and admittance (ANSI s3.39). New York, ANSI.

Bennett, M.J. \& Weatherby, L.A. (1979). Multiple probe frequency acoustic reflex measurements. Scandinavian Audiology 8: 233-239.

Berlin, C.I. \& Cullen, J.K. (1980). The physical basis of impedance measurement. In Jerger, J. \& Northern, J (Eds) Clinical Impedance Audiometry (2nd Ed), American Electromedics Corp.

Block, M.G. \& Wiley, T.L. (1986). Acoustic-reflex growth for multitone complexes. Journal of Speech and Hearing Research 29: 92-98.

Creten, W.L., Van de Heyning, P.H. \& Van Camp, K.J. (1985). Immittance audiometry: normative data at 220 and $660 \mathrm{~Hz}$. Scandinavian Audiology 14: 115-121.

Feldman, A.S. \& Williams, P.S. (1976). Tympanometric measurement of the transmission characteristics of the ear with and without the acoustic reflex. Scandinavian Audiology 5: 43-47.

Fitz-Gibbon, C.T. \& Morris, L. (1987). How to Analyze Data. Newbury Park, Sage.

Funasaka, S. \& Kumakawa, K. (1988). Tympanometry using a sweepfrequency probe tone and its clinical evaluation. Audiology 27: 99-1008.

Grason-Stadler. (1989) GSI 33, Version 2 Middle-Ear Analyzer Instruction Manual 1733-0121, Rev, 2, Grason-Stadler, Inc.

Greenfield, D.G., Wiley, T.L. \& Block, M.G. (1985). Acoustic reflex dynamics and the loudness discomfort level. Journal of Speech and Hearing Disorders 50, 14-20.

Hall, J.W. (1979). Effects of age and sex on static compliance. Archives of Otolaryngology 105: 153-156.

Lilly, D.L. \& Shanks, J.E. (1981). Acoustic immittance of an enclosed volume of air. In Popelka, G.R. (Ed) Hearing Assessment with the Acoustic Reflex Grune and Stratton.

Lutman, M.E. (1984). Phasor Admittance measurements of the middle ear I: theoretical aspects. Scandinavian Audiology 13: 253-264.

Lutman, M.E. \& Martin, A.M. (1977). The response of the acoustic reflex as a function of the intensity and temporal characteristics of pulsed stimuli. Journal of Sound and Vibration 54(3) 345-360.

Lutman, M.E. \& Martin, A.M. (1979). Development of an electracoustic analogue model of the middle ear and acoustic reflex. Journal of Sound and Vibration 64 (1) 133157.

Lutman, M.E., McKenzie, H. \& Swan, R.C. (1984). Phasor admittance of the middle ear II: normal phasor tympanograms and acoustic reflexes. Scandinavian Audiology13: 265-274

Margolis, R.H. (1981). Fundamentals of acoustic immittance. In Popelka, G.R. (Ed) Hearing Assessment with the Acoustic Reflex. Grune and Stratton.

Margolis, R.H., Van Camp, K.J., Wilson, R.H. \& Creten, W.L. (1985). Multifrequency tympanometry in normal ears. Audiology 24: 44-53.

Möller, A.R. (1961). Network model of the middle ear. Journal of the Acoustical Society of America 33(2), 168=176. 
Reynolds, L. (1991). Two component acoustic reflex measures across a range of probe frequencies. Presented at the South African Speech, Language and Hearing Association national Audioly Conference, Durban, South Africa, 16-18 October.

Reynolds, L. (1993). Two component acoustic reflex measures as function of probe frequency. Unpublished Master dissertation, University of Cape Town

Shanks, J.E., Lilly, D.J., Margolis, R.H., Wiley, T.L. \& Wilson, R.H. (1988). Tympanometry. Journal of Speech and Hearing Disorders 53 (4) 354-377.

Sprague, B.H., Wiley, T.L. \& Block, M.G. (1981). dynamics of acoustic reflex growth. Audiology 20: 15-40.

Van Camp, K.J. \& Creten, W.L. (1976). Principles of acoustic impedance and admittance. In Feldman, A.S. and Wilbur, L.A. (Eds) Acoustic Impedance and Admittance - the measurement of middle ear function. Williams \& Wilkins.
Vanhuyse, V.J., Creten, W.L. \& Van Camp, K.J. (1975). On the W-notching of tympanograms. Scandinavian Audiology 4: 45-50.

Wiley, T.L. \& Block, M.G. (1979). Static acoustic-immittance measurements. Journal of Speech and Hearing Research 22: 677-696, 1979 .

Wilson, R.H., \& McBride, L.M. (1978). Threshold and growth of the acoustic reflex. Journal of the Acoustical Society of America 63 (1) 147-164.

Wilson, R.H., Shanks, J.E., \& Kaplan, S.K. (1984). Tympanometric changes at $226 \mathrm{~Hz}$ and $678 \mathrm{~Hz}$ across 10 trials for two directions of ear canal pressure change. Journal of Speech and Hearing Research 27:257-266.

Yantis, P.A. (1985). Puretone air-conduction testing. In Katz, $\mathrm{J}$ (ed) Handbook of Clinical Audiology (3rd Ed) Williams and Wilkins. 